NOTE

\title{
Timing of deglaciation in the Cordillera de Talamanca, Costa Rica
}

\author{
Sally P. Horn \\ Department of Geography and Graduate Program in Ecology, University of Tennessee, Knoxville, Tennessee 37996-1420, USA
}

ABSTRACT: Radiocarbon analyses of lake sediments from the Chirripó massif of Costa Rica indicate that glaciers last retreated about 10000 yr BP. The 2 moraine complexes recognized on the massif apparently predate the $M$ III advance on the volcanoes of central Mexico.

Snowfall is unknown today in Costa Rica (Coen 1983), but during the Pleistocene snow fell and accumulated on the Chirripo massif in the Cordillera de Talamanca, forming several small glaciers. Ice-scoured basins, striated and smoothed rocks, and moraines have been mapped and described (Weyl 1956a, b, Hastenrath 1973, Bergoeing 1978, Barquero \& Ellenberg 1982-83) but the chronology of ice growth and decay has remained a matter of speculation. Weyl (1956a, b) first established the existence of a glacial episode on the Chirippó massif; based on the freshness of the glacial forms he suggested an age equivalent to the Würm-Wisconsin. Hastenrath (1973) identified 2 distinct sets of moraines on the massif: an older complex at valley exits that consists of up to 3 separate ridges and is composed of coarse, deeply weathered material, and a younger set of smaller moraines in the upper portions of the valleys characterized by finer material and a shallow humus layer. Hastenrath suggested that the larger and lower moraines belonged to the main period of glaciation, and that the smaller moraines upslope were appreciably younger and represented later, possibly recessional stages; however, he was unable to secure enough organic material within moraines to attempt radiocarbon dating. Here I report recent ${ }^{14} \mathrm{C}$ determinations on lake sediments that provide the first evidence available as to the timing of deglaciation in the mountains of Central America. The radiocarbon dates and sediment stratigraphy indicate that both sets of moraines in the Chirripo highlands were deposited before 10000 yr BP (before present), and that the region has been ice-free throughout the Holocene.
The Chirripó massif extends about $400 \mathrm{~m}$ above the present oak timberline and supports neotropical páramo vegetation dominated by the bamboo Chusquea (Swallenochloa) subtessellata (Horm 1989a). The uplifted granitic batholith that forms the backbone of the Cordillera de Talamanca is mantled here by Tertiary volcanics, which outcrop along with granitic rocks on peaks and in glacial basins. Cerro Chirripó (3819 m; $9^{\circ} 29^{\prime} \mathrm{N}, 83^{\circ} 29^{\prime} \mathrm{W}$ ) is the highest peak on the massif and in all of Costa Rica; it is a glacial horn surrounded by 3 cirques, 2 of which contain lakes dammed by moraines and rock thresholds. Seventeen other cirques, many also bearing lakes, have been mapped in adjacent areas (Barquero \& Ellenberg 1982-83).

As part of a study of postglacial vegetation history in the Chirripó highlands, 2 sediment cores were recently recovered from a glacial lake in the Valle de las Morrenas on the north side of Cerro Chirripó. The basin at the head of this valley (3450 to $3550 \mathrm{~m}$ elevation) contains several large lakes dammed by moraines that belong to the younger set identified by Hastenrath (1973). The cores were recovered from the largest lake $(3480 \mathrm{~m})$, which has a surface area of about 6 ha and a maximum depth of $8.3 \mathrm{~m}$. A horseshoe-shaped moraine $20 \mathrm{~m}$ high surrounds the lake (Hastenrath 1973).

The cores were raised from water depths of 6.4 and $7.5 \mathrm{~m}$ using a Livingstone piston sampler. Both cores penetrated to the base of the deposit, which consists of dark gray (Munsell 5Y 4/1) inorganic silt that presumably settled from glacial meltwater. About $5 \mathrm{~m}$ of black (10 YR 2/1), organic-rich lake sediment overlies the rock flour. Two samples from the base of the deeper water core were submitted for ${ }^{14} \mathrm{C}$ determination. The transition from glacial flour to organic sediment in this core begins sharply at $545 \mathrm{~cm}$ sub-bottom and is complete within $18 \mathrm{~cm}$. The first sample was from a sediment depth of 527 to $542.5 \mathrm{~cm}$ and consisted of lake sediment intermixed with mineral silt. The second sam- 
ple was from the adjacent interval of 515 to $527 \mathrm{~cm}$ subbottom and consisted of dark organic lake mud. The resulting dates were $10140 \pm 120 \mathrm{yr} B P$ (Beta-31787) for the first sample and $8900 \pm 100 \mathrm{yr} B P$ (Beta-30435) for the second sample. Four additional samples from higher levels in the core were submitted for radiocarbon analyses; the results confirm a normal stratigraphic sequence.

In his 1981 monograph on the glaciers of Ecuador Hastenrath included a synopsis of glacial events throughout the tropics in which he suggested that moraines in the Cordillera de Talamanca may correlate with the M III complex on the Mexican volcanoes, although he cautioned that the uppermost Chirripó moraines could be younger. The radiocarbon dates on the Morrenas lake sediments indicate that even the youngest moraines predate the MIII glaciation, shown by Heine (1984) to have occurred between roughly 10000 and 8500 yr BP. A. correlation with the Mexican M II glaciation about 12000 yr BP (Heine 1984) is possible.

In a more recent review of tropical glacier fluctuations, Hastenrath (1985) stressed similarities in the timing of deglaciation in Central Mexico, the Northern Andes, East Africa, and New Guinea. Hastenrath reported, as did Flenley (1979) some years earlier based on fewer sites, that dates for ice retreat were scattered over a span of almost $7000 \mathrm{yr}$ but showed good consistency between regions if elevation was taken into account. For the tropics as a whole, deglaciation was found to have progressed broadly from about $3000 \mathrm{~m}$ after ca $15000 \mathrm{yr}$ BP to about $4500 \mathrm{~m}$ at $8000 \mathrm{yr}$ $\mathrm{BP}$, with a lag of about $1000 \mathrm{yr}$ per $200 \mathrm{~m}$ elevation. The date of ca 10000 yr BP for the deglaciation of the upper Valle de las Morrenas in the Chirripó highlands falls within this time frame, but is later than would be expected based on the proposed relationship between minimum deglaciation ages and elevation. Dates of from 1 to 3 millennia earlier have been reported from sites that are at similar elevations or are up to $600 \mathrm{~m}$ higher. Two possibilities come to mind. The first is that the absence of an appreciable 'mountain mass effect' in the Cordillera de Talamanca (Hastenrath 1968) resulted in the longer persistence of ice here than at comparable altitudes on more extensive mountain masses that experience such a heating. The second possibility is that the timing of deglaciation in the tropics is simply less consistent than suggested by previously available data. Further dating of glacial deposits in the Cordillera de Talamanca and on other tropical mountains should shed light on the issue. Of particular interest would be to compare the timing of deglaciation in the Chirripó highlands with that in the Altos de Cuchumatanes, Guatemala, which like the Chirripó massif is presently ice-free but supported glaciers in the past (Hastenrath 1974).
The continuous nature of the organic sediments that overlie the glacial flour at the base of the Morrenas sediment cores indicates that the watershed has been ice-free since the final recession of the Late Pleistocene glaciers. A $110 \mathrm{~cm}$ sediment core recovered from a lake in the adjacent Valle de los Lagos in 1985 (Horn 1989b) does not cover the entire postglacial period, but shows that this valley has been ice-free since at least $4100 \mathrm{yr}$ $\mathrm{BP}$ when the organic-rich sediments that comprise the core began accumulating. No stratigraphic or geomorphic evidence of Neoglacial ice accumulation has been found on the Chirripó massif, nor anywhere else between the central Mexican volcanoes and the northern Andes, presumably because of insufficiently high summit elevations (Hastenrath 1981, 1985).

Acknowledgements. Fieldwork and radiocarbon analyses were supported by the National Geographic Society. I thank Douglas D. Baird, Jr, Brian Kermath, and Michael Mitchell for field assistance under difficult conditions, and the Costa Rican National Park Service, the University of Costa Rica Geography Department, and the people of San Gerardo, Costa Rica, for logistical support.

\section{LITERATURE CITED}

Barquero, J., Ellenberg, L. (1982-83). Geomorfología del piso alpino del Chirripó en la Cordillera de Talamanca, Costa Rica. Revta geográfica América Central 17-18: 293-299

Bergoeing, J. P. (1978). La fotografía area y su aplicación a la geomorfología de Costa Rica. Instituto Geográfico Nacional, San José, Costa Rica

Coen, E. (1983). Climate. In: Janzen, D. H. (ed.) Costa Rican natural history. University of Chicago Press, Chicago, p. $35-46$

Flenley, J. R. (1979). The Late Quaternary vegetation history of the equatorial mountains. Prog. phys. Geog. 3: 488-509

Hastenrath, S. (1968). Certain aspects of the three-dimensional distribution of climate and vegetation belts in the mountains of Central America and southern Mexico. In: Troll, C. (ed.) Geo-ecology of the mountainous regions of the tropical Americas. Ferd. Dümmers Verlag, Bonn, p. $122-130$

Hastenrath, S. (1973). On the Pleistocene glaciation of the Cordillera de Talamanca, Costa Rica. Z. Gletscherkd. Glazialgeol. 9: 105--121

Hastenrath, S. (1974). Spuren pleistozäner Vereisung in den Altos de Cuchumatanes, Guatemala. Eiszeitalter Ggw 25 $25-34$

Hastenrath, S. (1981). The glaciation of the Ecuadorian Andes A. A. Balkema, Rotterdam

Hastenrath, S. (1985). A review of Pleistocene to Holocene glacier variations in the tropics. Z. Gletscherkd. Glazialgeol. 21: 183-194

Heine, K. (1984). Comment on 'Pleistocene glaciation of Volcano Ajusco, Central Mexico, and comparison with the standard Mexican glacial sequence' by Sidney E. White and Salvatore Valastro, Jr. Quat. Res. 22: 242-246

Horn, S. P. (1989a). Postfire vegetation development in the Costa Rican páramos. Madroño 36 (2) : 93-114 
Horn, S. P. (1989b). Prehistoric fires in the Chirripo highlands of Costa Rica: sedimentary charcoal evidence. Revta. Biol. trop. 37 (2): 139-148

Weyl, R. (1956a). Spuren eiszeitlicher Vergletscherung in der

Editor-Professor V. Meentemeyer
Cordillera de Talamanca Costa Ricas (Mittelamerika). Neues Jahrb. Geol. Palaeontol. Abh. 102: 283-294 Weyl, R. (1956b). Eiszeitliche Gletscherspuren in Costa Rica (Mittelamerika). Z. Gletscherkd. Glazialgeol. 3: 317-325

Manuscript first received: June 5, 1990 Accepted: June 12, 1990 